\title{
OPTIMIZATION OF ENZYME ACTIVITY OF L-ASPARAGINASE DERIVED FROM Enterobacter agglomerans SB 221 BACTERIAL SYMBIONT OF BROWN ALGAE Sargassum sp.
}

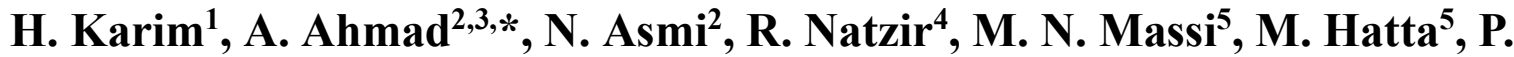 \\ Kabo $^{6}$, M. N. Djide ${ }^{7}$, R. Minhajat ${ }^{8}$, Z. Hasyim ${ }^{9}$, and M. Ibrahim ${ }^{10}$ \\ ${ }^{1}$ Department of Pharmacy, YAMASI, Jl. Mapala 2 Blok D5 No.10 Makassar Indonesia \\ ${ }^{2}$ Chemistry Department, Natural Science Faculty, Hasanuddin Univesity, Makassar, Indonesia \\ ${ }^{3}$ Laboratory of Research Centre and Developing of Sciences, Faculty of Natural Sciences, \\ Hasanuddin University Makassar, Indonesia \\ ${ }^{4}$ Biochemistry Department, Faculty of Medicine, Hasanuddin Univesity, Makassar, Indonesia \\ ${ }^{5}$ Microbiology Department, Faculty of Medicine, Hasanuddin Univesity, Makassar, Indonesia \\ ${ }^{6}$ Pharmacology Department, Faculty of Medicine, Hasanuddin Univesity, Makassar, Indonesia \\ ${ }^{7}$ Microbiology Department, Faculty of Pharmacy, Hasanuddin Univesity, Makassar, Indonesia \\ ${ }^{8}$ Histology Department, Faculty of Medicine, Hasanuddin Univesity, Makassar, Indonesia \\ ${ }^{9}$ Biology Department, Natural Science Faculty, Hasanuddin Univesity, Makassar, Indonesia \\ ${ }^{10}$ Inc. Ismut Fitomedika Indonesia, Makassar 90224, Indonesia \\ *E-mail: ahyarahmad@gmail.com
}

\begin{abstract}
L-asparaginase an enzyme belonging to the class of hydrolases which enable hydrolyze L-Asparagine to L-aspartic acid and ammonia is used in leukemia cancer treatment. L-asparaginase was purified from Enterobacter agglomerans SB 221, epiphytic bacterial symbiont of brown algae, Sargassum sp. This research aimed to optimize the concentration of L-Asn substrate, fermentation time, and $\mathrm{CoCl}_{2}$ concentration for high enzyme production. Also, the optimum $\mathrm{pH}$, temperature, and $\mathrm{CoCl}_{2}$ concentration for the most efficient enzymatic activity were determined. Nessler Method determined the enzymatic activity of L-asparaginase. The optimum concentration of L-Asn substrate was found to be $10 \mathrm{~g} / \mathrm{L}$ with the fermentation time of 48 hours, and the activity value of $49.572 \mathrm{U} / \mathrm{mL}$. The optimum concentration of $\mathrm{CoCl}_{2}$ was $1.9 \mathrm{mM}$, with an activity value of $72.236 \mathrm{U} / \mathrm{mL}$ and the protein concentration of $0.2269 \mathrm{mg} / \mathrm{mL}$. Enzyme activity was optimum at $\mathrm{pH} 8$ and $37^{\circ} \mathrm{C}$ temperature, yielding an activity value of $71.842 \mathrm{U} / \mathrm{mL}$. The optimum concentration of $\mathrm{CoCl}_{2}$ was $0.25 \mathrm{mM}$, with an activity value of $111.315 \mathrm{U} / \mathrm{mL}$. These findings suggest that the enzyme activity of L-asparaginase can be increased by the addition of $10 \mathrm{~g} / \mathrm{L}$ of L-Asn as the substrate and $0.25 \mathrm{mM}^{\circ} \mathrm{CoCl}_{2}$ as the cofactor. Sargassum binderi, the most abundant algae in the seawaters of Indonesia, can be used as a natural source of anticancer therapy, especially leukemia.
\end{abstract}

Keywords: Enterobacter agglomerans SB 226, L-asparaginase, $\mathrm{CoCl}_{2}$, L-Asn.

(C) RASĀYAN. All rights reserved

\section{INTRODUCTION}

Algae are well-known for their ability to associate with marine bacteria. The interaction between algae and bacteria occurs in the form of commensalism symbiosis and this interaction produces bioactive compounds. One species of algae, brown algae (Sargassum sp.), is a Sargassum genus from the class of Phaeophyceae. The use of symbiosis bacteria at marine organisms is to produce many proteins and enzymes that have been carried out previously ${ }^{1}$. These have been conducted by Wahyudi $a t$ al. $^{2}$ and Paratitis ${ }^{3}$. One of the identified symbiotic bacteria from brown macroalgae Sargassum sp. is Enterobacter agglomerans (E. agglomerans) SB 221. This bacteria is found to be able to produce L-Asparaginase (L-Asnase) enzyme,

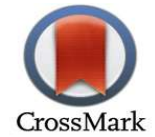


RASĀYAN J. Chem.

Vol. 13 | No. 3 |1571-1579| July - September | 2020

especially in F4 fraction from ammonium sulfate precipitation that able to hydrolyze L-Asn into ammonia and aspartic acid in its medium, subsequently, the $\mathrm{pH}$ change of the medium that is indicated by their colors turning from yellow to pink during 24 hours of incubation ${ }^{4}$.

L-Asparagine (L-Asn), one of the essential amino acids, is needed by normal and cancer cells. Administration of L-Asnase to cancer cells can decompose L-Asn, so it is expected to inhibit cell growth. L-Asnase provides great benefits in cancer therapy, especially acute lymphoblastic leukemia (ALL) ${ }^{5,6}$. In various studies on L-Asnase, several cofactor compounds were used to increase its activity, such as research conducted by Phetsri et al. that showed the increase of L-Asnase activity from Bacillus subtilis bacteria resulted from the addition of $\mathrm{Co}^{2+}, \mathrm{Fe}^{2+}, \mathrm{Mg}^{2+}$ in the concentration of $0.5 \mathrm{mM}^{7}$. Based on the description and introduction above, this study aims to explore E. agglomerans SB 221 bacteria, which is associated with brown algae Sargassum binderi as a new source of L-Asnase enzyme and to study the effect of adding $\mathrm{Co}^{2+}$ ion to the activity of the L-Asnase enzyme.

\section{EXPERIMENTAL}

\section{Materials}

The materials of this study were E. agglomerans SB 221 bacteria, distilled water, $\mathrm{KH}_{2} \mathrm{PO}_{4}$ (pa), $\mathrm{MgSO}_{4} .7 \mathrm{H}_{2} \mathrm{O}(\mathrm{pa}), \mathrm{CaCl}_{2} \cdot 2 \mathrm{H}_{2} \mathrm{O}, \mathrm{NaCl}$, glucose, L-Asn (pa), agar, red phenol indicator, Nutrient Broth $\mathrm{NB}$ media, NA media, Bovine Serum Albumin (BSA), Physiological $\mathrm{NaCl}, 70 \%$ alcohol, $\mathrm{CoCl}_{2}, \mathrm{NaCl} 0.2 \mathrm{M}$; $0.01 \mathrm{M} \mathrm{CaCl}_{2}$, Lowry A, Lowry B, ammonium chloride, Tris- $\mathrm{HCl}$ buffer $\mathrm{pH}$ 6-10, Nessler reagent, and trichloroacetate acid (TCA).

\section{Instruments}

The apparatus on this study were Petri dishes, test tubes, test tube racks, inoculation loops, ovens, incubators, UV light devices, shaker incubator, centrifugation, gloves, bunsen, stirring rods, Erlenmeyer, $\mathrm{pH}$ meters, hot plates, tweezers, Electronics $20 \mathrm{D}^{+}$, micro pipets, analytical scales, microscopes, objectglass, cover glass, Eppendorf tubes, and glassware commonly used in laboratories.

\section{Methods \\ Bacterial Rejuvenation}

Rejuvenation of E. agglomerans SB 221 bacteria from brown macroalgae symbiont Sargassum binderi was carried out by growing the bacterial stock of Biochemistry Laboratory, Natural Sciences Faculty, University of Hasanuddin, Makassar, Indonesia, on a growth medium plate. The medium components were Potassium dihydrogen phosphate $0.75 \mathrm{~g} / \mathrm{L}, \mathrm{L}-\mathrm{Asn} 10 \mathrm{~g} / \mathrm{L}$, Sodium Chloride $0.5 \mathrm{~g} / \mathrm{L}$, Magnesium sulphate heptahydrate $1.0 \mathrm{~g} / \mathrm{L}$, Calcium Chloride dihydrate $1.0 \mathrm{~g} / \mathrm{L}$, glucose $3 \mathrm{~g} / \mathrm{L}$, and the red phenol indicator $0.05 \mathrm{~g} / \mathrm{L}$ (a selective modified M-9 medium for the production of L-Asnase $\left.{ }^{8,9}\right)$. The growing bacteria were incubated for 24 hours at $37^{\circ} \mathrm{C}$.

\section{Determination of Optimum L-Asn Substrate Concentration and Fermentation Time on Enzyme Production}

Before the enzyme production, the optimum concentration of the L-asparagine substrate and production time for the L-Asnase enzyme were determined. The rejuvenated pure isolate was cultivated in fermentation and/or production medium to test L-Asnase enzyme activity. This process was started by making the inoculum and then proceeded with the fermentation process (production of enzyme). Ten milliliters of the inoculum that had been incubated for 24 hours at $37^{\circ} \mathrm{C}$ and $200 \mathrm{rpm}$ was taken and inoculated into $90 \mathrm{~mL}$ of production medium consisting of various concentrations of L-Asn substrates of $6,8,10,12$, and $14 \mathrm{~g} / \mathrm{L}$ in every 12 hours. Sampling was conducted up to 72 hours, and then the microbial growth was measured according to its OD (Optical Density) using a UV-VIS spectrometer at the $\lambda$ max of $646 \mathrm{~nm}$. The activity of the enzyme produced in the fermentation products was determined based on the amount of ammonia released from the harvested sample after treated with Nessler reagent following the L-Asnase activity determination method $^{7,10}$ described in detail below.

Ammonia level was calculated by substituting the obtained absorbance into the standard curve equation of ammonium chloride solution from the regression equation of $y=a x+b$, so- 
RASĀYAN J. Chem.

$\mathrm{x}=\frac{(\mathrm{y}-\mathrm{b})}{\mathrm{a}}$

Vol. 13 | No. 3 |1571-1579| July - September | 2020

Where:

$\mathrm{y}=$ absorbance

$\mathrm{x} \quad=$ ammonia level $(\mu \mathrm{mol} / \mathrm{L})$

$\mathrm{a} \quad=$ slope

$\mathrm{b} \quad=$ intersept

The L-Asnase activity value was obtained by using the following equation:

Enzyme activity $(\mathrm{U} / \mathrm{mL})=\frac{y-b}{a} \times \frac{V \text {.Total }}{V \cdot \text { Analysis }} \times \frac{1}{V . \text { Enzyme }} \times \frac{1}{\text { t.Incubation }}$

abbreviation:

V. Total $=\quad$ Volume of enzyme + substrate + buffer + TCA $(2.5 \mathrm{~mL})$

V. Analysis $\quad=\quad$ Total volume analyzed $(0.5 \mathrm{~mL})$

V. Enzyme $\quad=\quad$ Volume of enzyme analyzed $(0.1 \mathrm{~mL})$

$\mathrm{t}$ Incubation $=10$ minutes

One unit Activity of L-Asnase $=$ volume of L-Asnase enzyme that catalyzes L-Asn substrate to release one $\mu \mathrm{mol}$ of ammonia per minute under the test condition.

\section{Determination of Optimum $\mathrm{CoCl}_{\mathbf{2}}$ Concentration and Fermentation Time on L-Asnase Production}

The determination of the optimum $\mathrm{CoCl}_{2}$ concentration was conducted as well before final enzyme production. Rejuvenated pure isolates were cultivated in fermentation and or production medium to test LAsnase enzyme activity. This process was started with the preparation of the inoculum then proceeded with the fermentation process (production of enzyme). Ten milliliters of the inoculum that had been incubated for 24 hours at $37{ }^{\circ} \mathrm{C}$ and $200 \mathrm{rpm}$ was taken and inoculated into $90 \mathrm{~mL}$ of production medium consisting of various concentrations of $\mathrm{CoCl}_{2}(0 ; 1.9 ; 3.8 ; 5.7 ; 7.6$; or $9.6 \mathrm{mM})$. Next, the fermentation products were harvested every 12 hours up to a total of 72-hour fermentation. Then, the microbial growth in the harvested sample products was determined based on their OD measured spectrophotometrically at $646 \mathrm{~nm}$ and also L-Asnase activity from the crude enzyme extract described in detail above (equation 1).

\section{Protein Level Measurement}

The protein level of the fermentation products from the optimum $\mathrm{CoCl}_{2}$ concentration overtime was also measured. The determination of protein level was carried out by a modified Lowry method using BSA as the standard solution ${ }^{12,15}$.

\section{Characterization of L-Asnase Enzyme produced under the optimum L-Asn substrate and $\mathrm{CoCl}_{2}$ concentrations, and fermentation time Effect of pH on L-Asnase Enzyme Activity}

L-Asnase activity of the enzymes produced (as crude enzyme extract) under the optimum condition was evaluated at various $\mathrm{pHs}$. The enzyme was incubated in $0.05 \mathrm{M}$ Tris- $\mathrm{HCl}$ buffer at various $\mathrm{pH}$ from 6 to 10 with 1.0 increment. In each test condition, the amount of the released ammonia after treatment with Nessler reagent in the incubated samples was measured to determine their enzyme activity. The incubation was conducted for 10 minutes, followed by centrifugation and then the obtained filtrate was evaluated for its enzyme activity ${ }^{7,10}$.

\section{Effect of Temperature on L-Asnase Enzyme Activity}

L-Asnase activity was evaluated at various temperatures at optimum $\mathrm{pH}$. The samples test was incubated at temperatures of $30,35,37,40$, and $45^{\circ} \mathrm{C}$. In each test condition at various temperatures, the amount of the released ammonia after treatment with Nessler reagent in the incubated samples was measured to determine their enzyme activity. The incubation was conducted for 10 minutes, followed by centrifugation and then the obtained filtrate was evaluated for its enzyme activity ${ }^{7,10}$.

\section{Effect of Cofactor $\mathrm{CoCl}_{2}$ Concentrations on the Activity of the L-Asnase Enzyme}

Buffer solution having the optimum $\mathrm{pH}(0.2 \mathrm{~mL})$ was mixed with $0.1 \mathrm{~mL}$ enzyme (crude enzyme extract), and then $0.3 \mathrm{~mL}$ of $\mathrm{CoCl}_{2}$ with a concentration of $0.075 ; 0.100 ; 0.250 ; 0.500$; or $0.750 \mathrm{mM}$, and $1.7 \mathrm{~mL}$ 
RASĀYAN J. Chem.

Vol. 13 | No. 3 |1571-1579| July - September | 2020

of L-Asn amino acid $0.01 \mathrm{M}$ were added. After that, the mixture was incubated for 10 minutes at the optimum temperature determined before, and then $0.2 \mathrm{~mL}$ of $0.5 \mathrm{M}$ TCA was added and centrifuged. The enzyme activity was determined, described in detail above (equation 1) to evaluate the optimum concentration of the $\mathrm{CoCl}_{2}^{7,10}$.

\section{RESULTS AND DISCUSSION}

This study used E. agglomerans SB 221 bacteria as a source of the L-Asnase enzyme. In general, enzyme production, especially L-Asnase, is strongly affected by substrate concentration, the concentration of cofactor, $\mathrm{pH}$, and temperature. Therefore, we will discuss these matters in this study.

\section{Determination of L-Asn Substrate Concentration and the Optimum Production Time of L-Asnase Enzyme}

Determination of the optimum concentration of L-Asn substrate and the optimum production time of LAsnase enzyme through the determination of OD (optical density) in L-Asnase production medium was carried out by inoculating the selected bacterial colonies of 24-hour-old E. agglomerans SB 221 into the liquid inoculum medium with the variation of L-Asn concentrations $(6,8,10,12$, or $14 \mathrm{~g} / \mathrm{L})$. The inoculum media was cultivated on a shaker incubator at $200 \mathrm{rpm}$ for 24 hours at $37^{\circ} \mathrm{C}$. Subsequently, the inoculum media was mixed in the production medium at various substrate concentrations of $10 \mathrm{~mL}$. The optimum incubation time was determined by measuring OD of the cell cultures and L-Asnase activity every 12 hours with an incubation time of 72 hours. The relationship between the incubation time and the $\mathrm{OD}_{646 \mathrm{~nm}}$ of the culture medium on various of the substrate concentration of L-Asn were shown in Fig.-1A. The results showed that the maximum OD of the cell cultures was 1.47 when the L-Asn substrate concentration in the fermentation medium was $10 \mathrm{~g} / \mathrm{L}$ at 24 hour incubation time.

On the other hand, the activity of L-Asnase was determined using the Nessler method, specifically the amount of ammonia produced from the hydrolysis of L-Asn amino acid substrate by L-Asnase enzyme expressed by its activity. Ammonia released by the hydrolysis of the L-Asnase enzyme activity with Nessler reagent. Afterward, ammonium chloride was used as a standard solution in determining the activity of the L-Asnase enzyme. L-Asnase unit (IU) was defined as the amount of the L-Asnase enzyme that catalyzed the formation of one $\mu \mathrm{mol}$ ammonia per minute under the experiment conditions ${ }^{11,12}$. The results showed that the maximum activity of L-Asnase was $49.5729 \mathrm{U} / \mathrm{mL}$ when the L-Asn substrate concentration in the fermentation medium was $10 \mathrm{~g} / \mathrm{L}$ at 48 -hour incubation time, as shown in Fig.-1B.

Determination of $\mathrm{CoCl}_{2}$ Concentration and the Optimum Production Time of L-Asnase Enzyme The next step was the production of L-Asnase enzyme during the fermentation process under the optimum concentration of L-Asn substrate and the addition of $\mathrm{CoCl}_{2}$ with various concentrations of $0 ; 1.9 ; 3.8 ; 5.7$; 7.6; and $9.5 \mathrm{mM}$. The addition of $\mathrm{CoCl}_{2}$ with various concentrations aimed to determine the concentration of L-Asnase enzyme that may increase the production yield. In this medium, microbial growth and crude extract enzyme products monitored properly according to optimal conditions during fermentation time. Sampling during the fermentation process was carried out every 12 hours for 3 days to determine the optimum time for OD of the cells cultures measurement, enzyme activity testing, and protein levels measurement. The relationship between the incubation time and the $\mathrm{OD}_{646} \mathrm{~nm}$ of the culture medium on various of the cofactor concentration of $\mathrm{CoCl}_{2}$ were shown in Fig.-2A. The results showed that the maximum OD of the cell cultures was 0.7 when the $\mathrm{CoCl}_{2}$ concentration in the fermentation medium was $1.9 \mathrm{mM}$ at 36 hour incubation time. On the other hand, the activity of L-Asnase during the fermentation process under the optimum conditions was determined using the Nessler method. The results showed that the optimum production time was at 48 hours, and the optimum concentration of $\mathrm{CoCl}_{2}$ was $1.9 \mathrm{mM}$, with L-Asnase activity of $72.236 \mathrm{U} / \mathrm{mL}$, as shown in Fig.-2B.

Effect of Fermentation Time on Protein Content and L-Asnase Enzyme Activity under the Optimum Substrate and $\mathrm{CoCl}_{2}$ Concentration

The total protein content in the enzyme solution was calculated by Lowry method ${ }^{12,15}$. In this method, the Lowry reagent used would react with protein and was indicated as a strong dark blue color. Measurement of crude extract protein level was carried out at the optimum $\mathrm{CoCl}_{2}$ concentration of $1.9 \mathrm{mM}(0.25 \mathrm{~g} / \mathrm{L})$ and L-Asn substrate concentration of $10 \mathrm{~g} / \mathrm{L}$ in various fermentation time. 
RASĀYAN J. Chem.

Vol. 13 | No. 3 |1571-1579| July - September | 2020

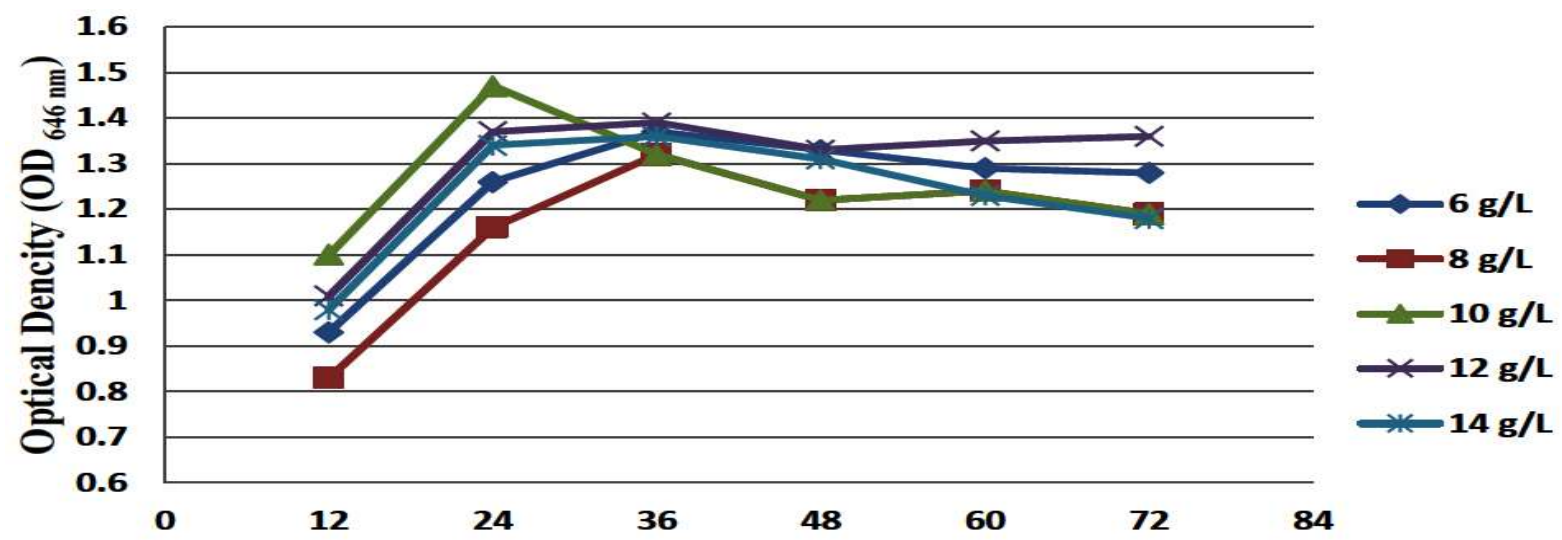

$\mathbf{A}$

Fermentation Time (hours)

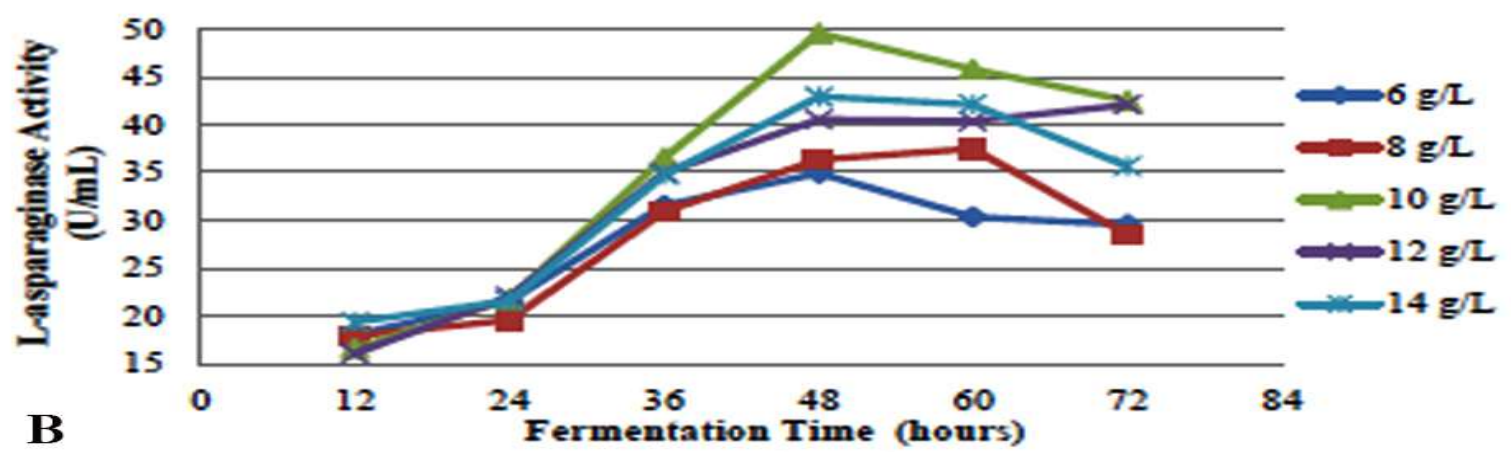

Fig.-1: Effect of L-Asn substrate concentration and fermentation time on optical density of E. agglomerans SB 221 cultures (A) and the activity of the L-Asnase enzyme (B) produced during cultivation in the fermentation medium
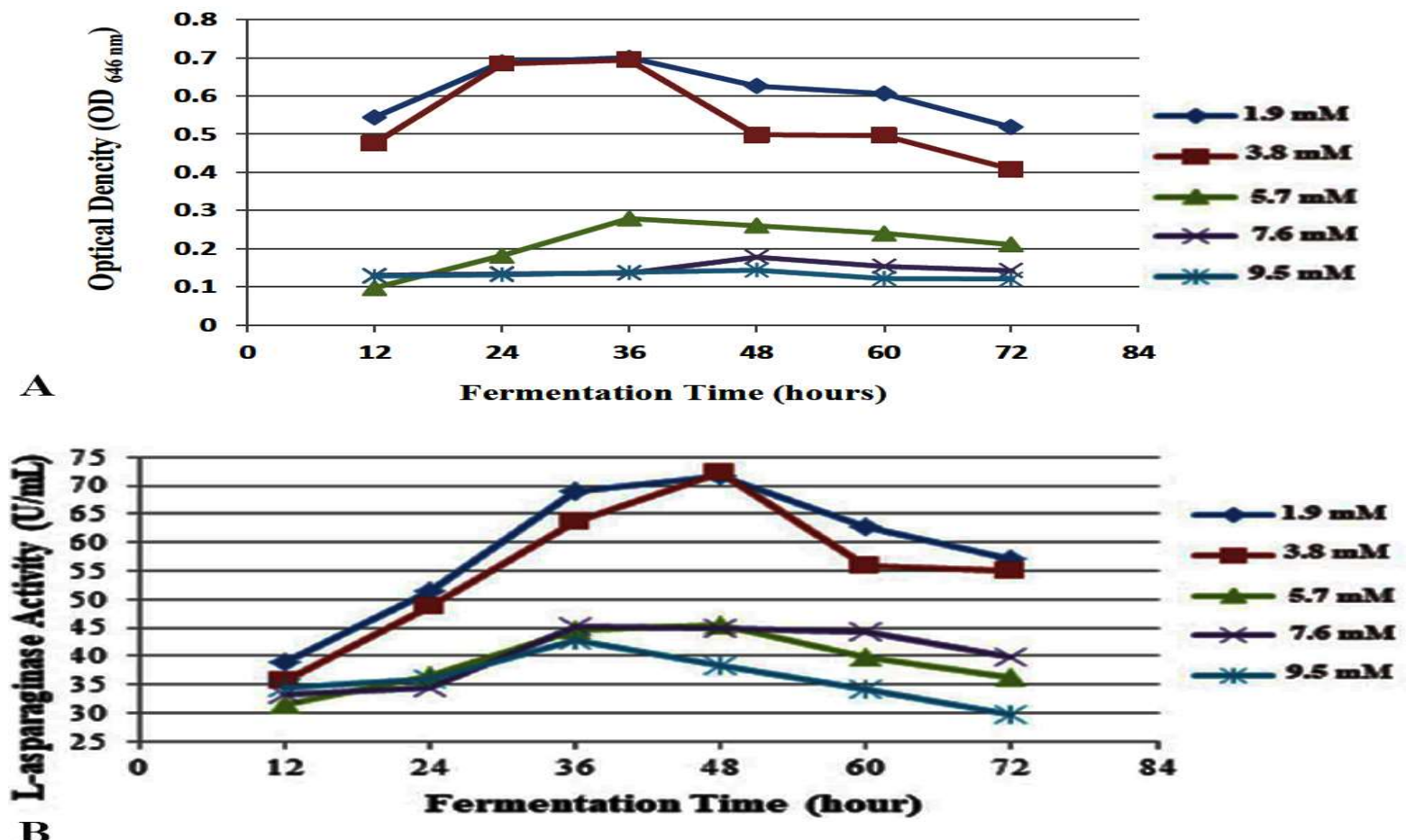

Fig.-2: Effect of $\mathrm{CoCl}_{2}$ concentration and fermentation time in the cultivation of E. agglomerans $\mathrm{SB} 221$ Bacteria on optical density (A) and L-Asnase enzyme activity (B) 
RASĀYAN J. Chem.

Vol. 13 | No. 3 |1571-1579| July - September | 2020

The amount of protein was determined based on the absorption of the solution at a wavelength of $640 \mathrm{~nm}$, which is the maximum wavelength of the BSA standard to obtain a standard curve. Based on this standard curve, a straight line equation was made to calculate the content level of L-Asnase protein. The result showed that maximum protein content was observed when the fermentation reached 36 hours of incubation, which was $0.3040 \mathrm{mg} / \mathrm{mL}$, while the maximum activity was $75.263 \mathrm{U} / \mathrm{mL}$ at 48 hours of fermentation (Fig.$3)$.

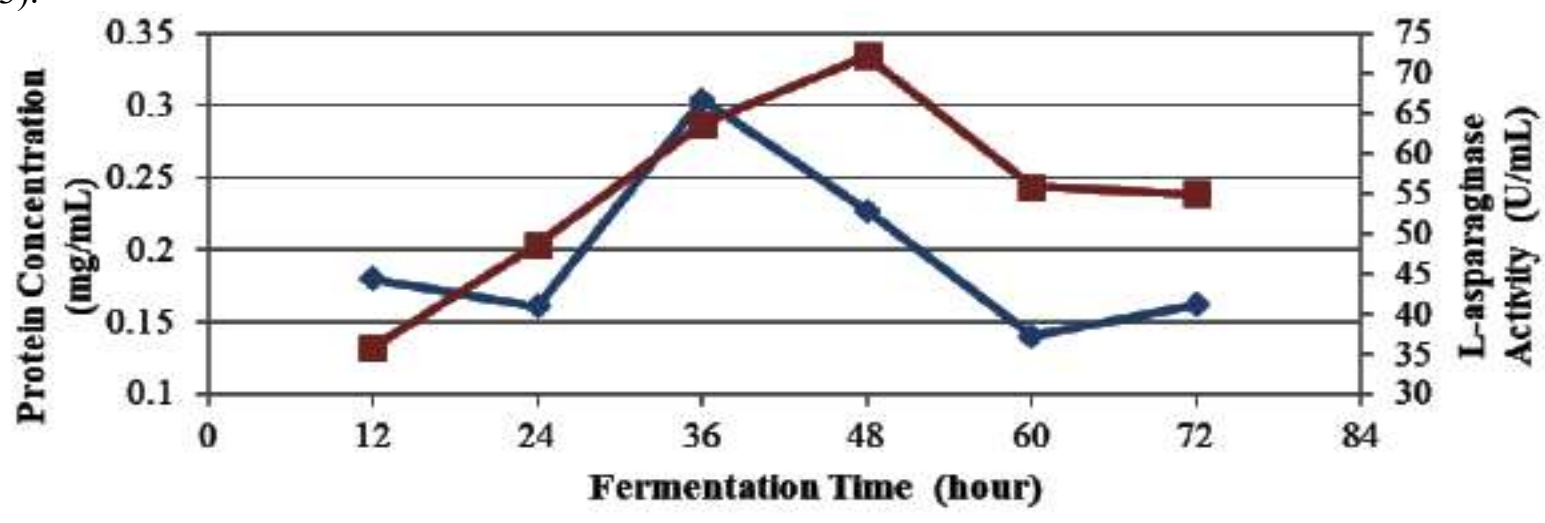

\section{$\rightarrow$ Protein concentration $\quad \rightarrow-$ Enzyme activity}

Fig.-3: Effect of fermentation time from the cultivation of E. agglomerans SB 221 bacteria at optimum substrate concentration and $\mathrm{Co}^{+2}$ ion on the protein level and L-Asnase enzyme activity.

\section{Characterization of the L-Asnase Enzyme}

The characterization of L-Asnase was conducted by testing the crude enzyme extract activity at various $\mathrm{pH}$ ranges, temperature, and the effect of the $\mathrm{CoCl}_{2}$ metal cofactor. It aims to know the properties and characteristics of the L-Asnase enzyme produced from E. agglomerans SB 221 against these influences. The characterized enzyme was L-Asnase enzyme that has maximum activity at the optimum substrate, optimum addition of $\mathrm{CoCl}_{2}$ to the enzyme production, and optimum fermentation time. The characterization of the enzyme was carried out in a range of $\mathrm{pH} 6-10$, the temperature of $30-45^{\circ} \mathrm{C}$, and the effect of $\mathrm{CoCl}_{2}$ cofactor addition at the concentrations of $0.075 ; 0.100 ; 0.250 ; 0.500$ and $0.750 \mathrm{mM}$.

\section{Effect of pH on L-Asnase Enzyme Activity}

The activity of an enzyme depends on the density of hydrogen ions where it acted. Each enzyme has its optimum $\mathrm{pH}$, a $\mathrm{pH}$ where the enzyme can work properly ${ }^{12}$. The activity of L-Asnase enzymes initially increased with the increase of $\mathrm{pH}$, specifically L-Asnase activity at $\mathrm{pH} 6$ was $44.22 \mathrm{U} / \mathrm{mL}$, and then increased to $59.06 \mathrm{U} / \mathrm{mL}$ at $\mathrm{pH} 7$, so that the enzyme activity at $\mathrm{pH} 8$ showed the highest value of 60.12 $\mathrm{U} / \mathrm{mL}$. The enzyme activity began to decreased at $\mathrm{pH} 9$ and 10 with an activity value of 57.88 and 54.20 $\mathrm{U} / \mathrm{mL}$, respectively. Based on the data obtained, it can be seen that the optimum $\mathrm{pH}$ of the obtained LAsnase enzyme in this study was at maximum the $\mathrm{pH}$, as seen in Fig.-4. The data have similarities with several previous studies but with different sources of the enzymes ${ }^{11,14,15}$. For instance, El-Naggar et al, reported that $\mathrm{pH} 8.5$ is the activity for L-Asnase obtained from Streptomyces brollosae NEAE-115 ${ }^{8}$. Another researcher reported that $\mathrm{pH} 7.0$ is the maximum activity for L-Asnase obtained from marine Bacillus licheniformis ${ }^{12,15}$. The optimum $\mathrm{pH}$ of the L-Asnase evaluated in this work showed that the enzyme could function very well at the physiological condition in the human body. Therefore, L-Asnase enzyme that is stable at physiological $\mathrm{pH}$ is a desirable property for the enzyme that is used as ALL disease therapeutics in the future.

\section{Effect of Temperature on L-Asnase Enzyme Activity}

The initial temperature increased to the optimum temperature will incline the rate of enzymatic reactions, but an increase in temperature above the maximum temperature will reduce the reaction rate ${ }^{16}$. The activity of the L-Asnase enzyme initially increased with the increasing value of the temperature so that the enzyme 
RASĀYAN J. Chem.

Vol. 13 | No. 3 |1571-1579| July - September | 2020

activity at $37^{\circ} \mathrm{C}$ showed the highest value of $61.12 \mathrm{U} / \mathrm{mL}$. The enzyme activity began to decline at a temperature of $40^{\circ} \mathrm{C}$ and $45^{\circ} \mathrm{C}$ with an activity value of 60.91 and $56.96 \mathrm{U} / \mathrm{mL}$, respectively. Based on the data obtained, it can be seen that the optimum temperature of the L-Asnase enzyme in this study was at $37^{\circ} \mathrm{C}$, described in Fig.-5. The results have the same with several previous studies but with different sources of enzymes ${ }^{11,14,17}$. The temperature optimum of L-Asnase has been reported as $37^{\circ} \mathrm{C}$ L-Asnase obtained from Streptomyces brollosae NEAE- $115^{8}$ and marine Bacillus licheniformis ${ }^{15}, 35^{\circ} \mathrm{C}$ from lactic acid bacteria $^{7}$, and $40^{\circ} \mathrm{C}$ from marine Aspergillus terreus ${ }^{5}$. These findings indicated that the L-Asnase enzyme of different microbial sources has different optimum conditions.

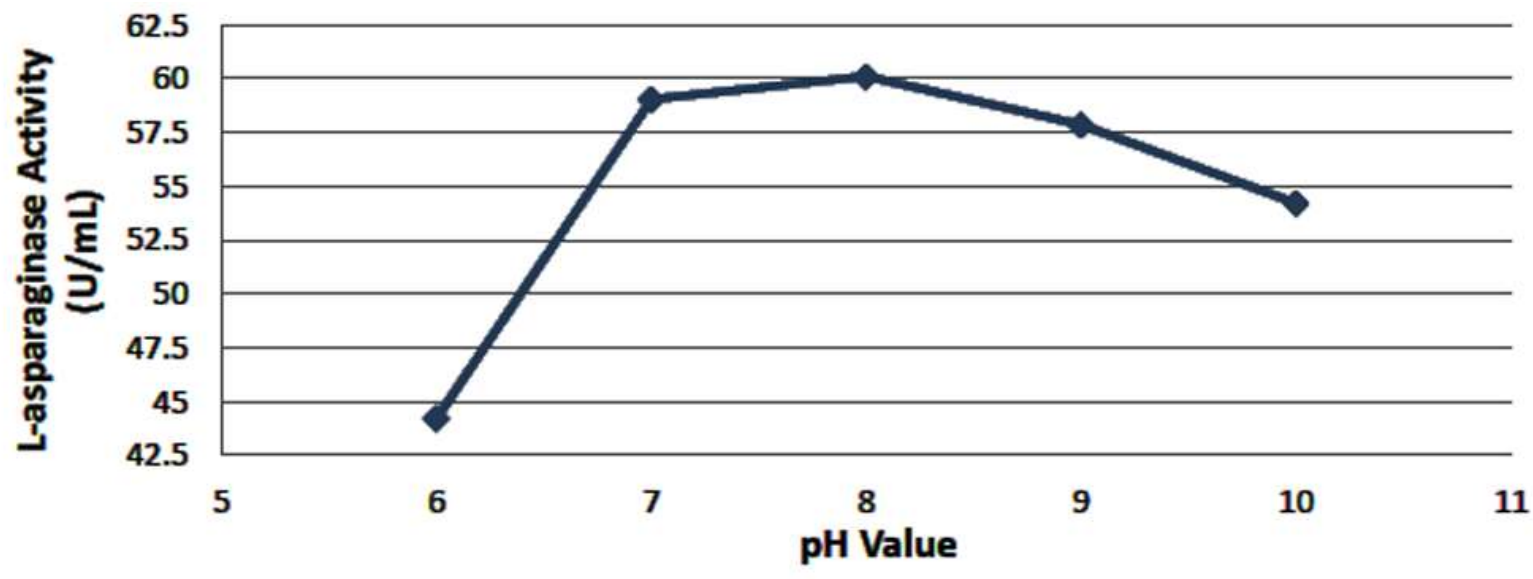

Fig.-4: Effect of $\mathrm{pH}$ on L-Asnase activity from E. agglomerans $\mathrm{SB} 221$ at the optimum substrate and $\mathrm{Co}^{+2}$ ion concentrations and the temperature of $37^{\circ} \mathrm{C}$

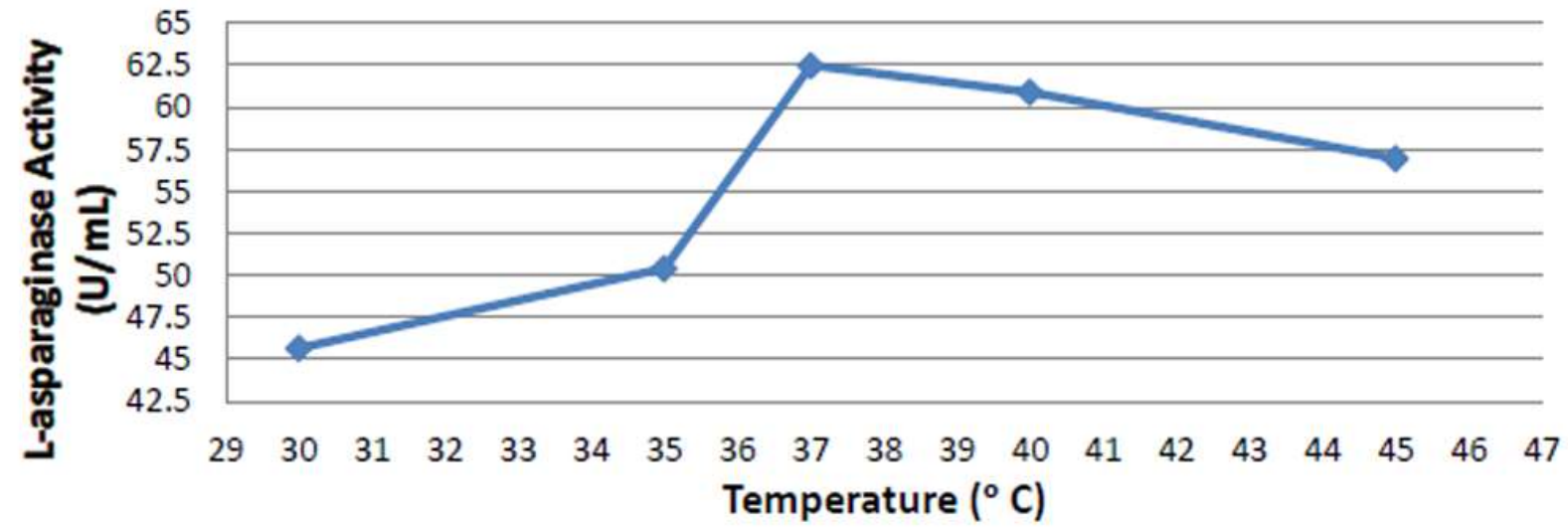

Fig.-5: Effect of temperature on L-Asnase activity from E. agglomerans SB 221 at optimum substrate concentration and $\mathrm{Co}^{+2}$ ion and $\mathrm{pH} 8$

The Effect of Optimum $\mathrm{CoCl}_{2}$ Cofactor Concentration on L-Asnase Enzyme Activity

Bacterial growth requires cofactor compounds as a source of minerals such as manganese, calcium, iron, nitrogen, sulfur, and magnesium because bacteria cells also need complete nutrition. This cofactor can act as an activator that can increase enzyme activity and as an inhibitor that can reduce enzyme activity ${ }^{7,18}$. The activity of the L-Asnase enzyme initially increased with the increasing $\mathrm{CoCl}_{2}$ cofactor concentration used so that at the concentration of $0.25 \mathrm{mM}$, the enzyme activity showed the highest value of $111.315 \mathrm{U} / \mathrm{mL}$. The enzyme activity began to decrease at a concentration of $0.5 \mathrm{mM}$, with an activity value of 106.578 $\mathrm{U} / \mathrm{mL}$.

Based on the data obtained in this research, it can be seen that the optimum $\mathrm{CoCl}_{2}$ concentration of the LAsnase enzyme in this study was at the concentration of $0.25 \mathrm{mM}$. Fig. -6 shows that L-Asnase activity increased with the increasing $\mathrm{CoCl}_{2}$ cofactor concentration to optimum at the concentration of $0.25 \mathrm{mM}$ and decreased at the concentration of $0.5 \mathrm{mM}$. L-Asnase activities at $\mathrm{CoCl}_{2}$ cofactor concentrations of $0.075,0.100,0.250,0.500$, and $0.750 \mathrm{mM}$ were $78.684 \mathrm{U} / \mathrm{mL}, 106.052 \mathrm{U} / \mathrm{mL}, 111.315 \mathrm{U} / \mathrm{mL}, 106.578$ 
RASĀYAN J. Chem.

Vol. 13 | No. 3 |1571-1579| July - September | 2020

$\mathrm{U} / \mathrm{mL}$, and $102.894 \mathrm{U} / \mathrm{mL}$, respectively. The results were different from several previous studies but with different bacterial species as sources of enzymes ${ }^{7,14}$.

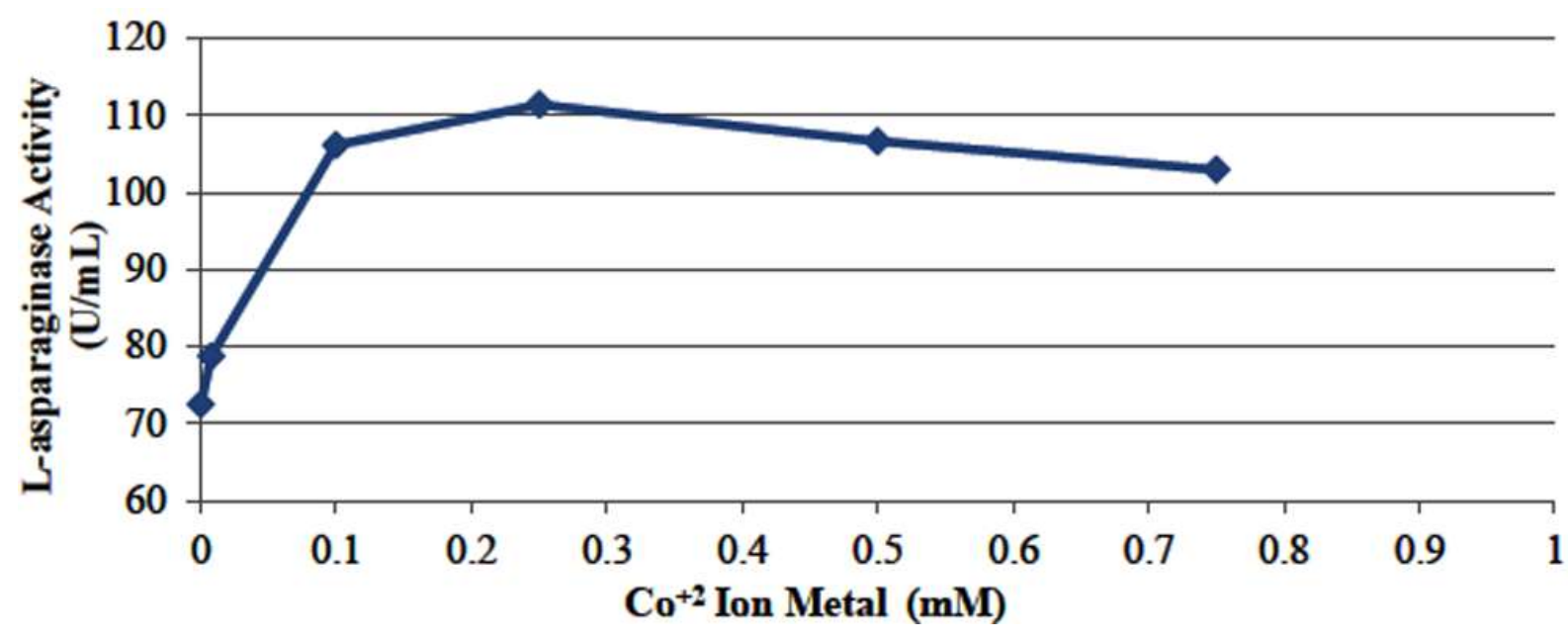

Fig.-6: Effect of $\mathrm{CoCl}_{2}$ concentration on L-Asnase activity from E. agglomerans SB 221 at optimum substrate concentration, $\mathrm{pH}$, and temperature.

\section{CONCLUSION}

Brown algae symbiont bacteria Sargassum binderi, namely E. agglomerans SB 221, can produce extracellular L-Asnase optimally when grown in the presence of L-Asn at the concentration of $10 \mathrm{~g} / \mathrm{L}$ and $\mathrm{CoCl}_{2}$ at the concentration of $1.9 \mathrm{mM}$ in the production medium with the incubation time of 48 hours. LAsnase enzyme produced under this condition has the optimum activity at $\mathrm{pH} 8$ and $37^{\circ} \mathrm{C}$ with the activity of 60.12 and $61.12 \mathrm{U} / \mathrm{mL}$, respectively, when $\mathrm{CoCl}_{2}$ cofactor is added into at the concentration of $0.25 \mathrm{mM}$ with the maximum activity of $111.32 \mathrm{U} / \mathrm{mL}$. L-Asnase is an enzyme capable of hydrolyzing L-Asn, which is a precursor of acrylamide, a compound that causes cancer. Therefore, the bioactivity test of L-Asnase enzyme as an anticancer at optimum conditions, including the optimum concentration of cofactor compounds, is necessary to be conducted as well in the future.

\section{ACKNOWLEDGEMENT}

The authors thank Dr. Ronny Horaks for the editorial reading of the manuscript. The authors also thank Mr. Ade for invaluable help in technical assistance and sample preparation and treatments in the Biochemistry Laboratory, University of Hasanuddin, Indonesia. This work was supported in part by a Grant-in-Aid from Graduate School of Team Research (The second year of PDD 2020, Contract No. 1517/UN4.22/PT.01.03/2020) program of Directorate of Research and Development and SABBATICAL LEAVE the program and also this research was partially funded by World Class University (WCU) Program, managed by Institut Teknologi Bandung of the KEMENRISTEKDIKTI of Indonesia.

1. A. Kadi, Oseana, 30 (4),19(2015).

\section{REFERENCES}

2. A.T. Wahyudi, Qatrunnada and N.R. Mubarik, Hayati Journal of Biosciences,17(4), 173(2010), DOI: 10.4308/hjb.17.4.173

3. Paratitis, Unpublished Thesis, Department Fishery and Marine Sciences, Institut Pertanian Bogor, Bogor, Indonesia (2006)

4. M. Artasasta, and A. Purwanti, Unpublished Thesis UNHAS, Makassar, (2014).

5. S. W. M. Hassan, A.M. Farag, and E. A. Beltagy, Journal of Pure and Applied Microbiology, 12(4), 1845(2018), DOI: 10.22207/JPAM.12.4.19

6. G. Karpel-Massler, D. Ramani, C. Shu, M-E. Halatsch, M-A. Westhoff, J.N. Bruce, P. Canoll, and M. D. Siegelin, Oncotarget, 7, 33512(2016), DOI:10.18632/oncotarget.9257 
RASĀYAN J. Chem.

Vol. 13 | No. 3 |1571-1579| July - September | 2020

7. K. Phetsri, M. Furukawa, R. Yamashiro, Y. Kawamura, J. Hayashi, R. Tobe, Y. Toyotake, and M. Wakayama, Journal of Biotechnology and Biomedicine, 2, 112(2019), DOI: 1026502/jbb.264291280015

8. N. E. El-Naggar, S. F. Deraz, S. M. El-Ewasy, and G. M. Suddek, BMC Pharmacol Toxicol., 19(51), 1(2018), DOI: 10.1186/s40360-018-0242-1

9. A. M., Farag, S. W., Hassan, E. A. Beltagy, and M. A. El-Shenawy, The Egyptian Journal of Aquatic Research, 41, 295 (2015), DOI:10.1016/j.ejar.2015.10.002

10. N. M. Saptarini, D. Rahayu and S.A.F. Kusuma, Rasayan Journal of Chemistry, 12(4), 2074(2019), DOI: $10.31788 /$ RJC.2019.1245319

11. S.A. Moharib, World Scientific Research, 5(1), 1(2018), DOI:10.20448/journal.510.2018.51.1.12

12. S. A. Alrumman, Y. S. Mostafa, K. A. Al-izran, M. Y. Alfaifi, T. H. Taha and S. E. Elbehairi, Scientific Reports, 9, 3756 (2019), DOI:10.1038/s41598-019-40512-x

13. D. Sumardjo, Introduction to Chemistry, Buku Kedokteran EGC, Jakarta (2006)

14. I. Husain, A. Sharma, S. Kumar and F. Malik, PLoS ONE, 11(2), e0148877(2016), DOI: 10.1371/journal.pone. 0148877

15. A. Ahmad, A.M. Patta and H. Natsir, International Journal of Pharma and Bio Science, 4(4), 274(2013)

16. A.M. Patta, Unpublished Thesis, Department of Chemistry, Hasanuddin University, Makassar, Indonesia (2013)

17. A. Singh, N. Verma and K. Kumar, International Journal of Pharmaceutical Sciences and Research, 9(12), 5394(2018), DOI: 10.13040/IJPSR

18. M.T. Suhartono, Enzymes and Biotechnology, PAU Biotechnology, Institut Pertanian Bogor, Indonesia (1989)

[RJC-5691/2020] 